\title{
ANALISIS POTENSI PENDIRIAN BMT GUNA MENINGKATKAN PEMBERDAYAAN EKONOMI MIKRO DI DESA SUMBERKOLAK KECAMATAN PANARUKAN SITUBONDO
}

\section{AN ANALYSIS OF POTENTIAL ESTABLISHMENT OF BMT TO IMPROVE MICRO ECONOMIC EMPOWERMENT AT SUMBERKOLAK VILLAGE, PANARUKAN SUB-DISTRICT, SITUBONDO}

\author{
Siti Soeliha \\ SitiSoeliha21@gmail.com \\ Universitas Abdurachman Saleh Situbondo
}

\begin{abstract}
ABSTRAK
Desa Sumber Kolak, Kecamatan Panarukan merupakan desa idaman yang pertumbuhan dan potensi ekonominya berkembang pesat. Desa ini juga mempunyai masyarakat yang terbuka dengan beberapa etnis adat yang mengutamakan nilai kebersamaan dan gotong royong dengan nilai agama yang didominasi umat Islam. Atas dasar falsafah dan nilai yag dimiliki oleh masyarakat maka diperlukan lembaga keuangan syariah BMT ( Baitul maal Waat tanwil) di Desa Sumber Kolak karena lembaga ini memiliki potensi untuk memberdayakan usaha mikro dan masyaraakat. Sehubungan dengan hal itu, penelitian ini dilakukan untuk mengetahui faktor internal dan faktor internal yang mempengaruhi pertumbuhan BMT. Data pada penelitian ini dianalisis secara deskriptif dengan mendeskripsikan hasil survei yang diperoleh dari kuisioner. Analisis SWOT penilaian terhadap faktor internal dan eksternal yang dimiliki BMT menunjukkan hasil positif yaitu terdapat selisih antara kekuatan dan kelemahan yang dimiliki BMT sebesar 0,99, sedangkan dari faktor eksternal terdapat selisih total antara peluang dan ancaman sebesar 0,54. Dari hasil ini, maka diperlukan upaya sosialisasi yang lebih intensif terhadap dan pendirian BMT.
\end{abstract}

Kata Kunci : Pendirian BMT, SWOT, Ekonomi Mikro

\section{ABSTRACT}

Sumber Kolak Village, Panarukan District is a dream village with rapid growth and economic potential. This village also has an open community with several indigenous ethnic groups that prioritize the value of togetherness and mutual cooperation with the religious values that are dominated by Muslims. On the basis of the philosophy and value of the community, a BMT (Baitul maal Waat tanwil) Islamic financial institution is needed in Sumber Kolak Village because this institution has the potential to empower micro businesses and communities. In this connection, this study was conducted to determine internal factors and internal factors that influence BMT growth. The data in this study were analyzed descriptively by describing the survey results obtained from the questionnaire. SWOT analysis of the assessment of internal and external factors owned by BMT showed positive results, namely the difference between strengths and weaknesses 
of BMT of 0.99, while from external factors there was a total difference between opportunities and threats of 0.54. From these results, more intensive socialization efforts are needed towards and the establishment of BMTs.

Keywords: Establishment of BMT, SWOT, Microeconomics

\section{PENDAHULUAN}

Sesuai dengan tujuan pembangunan nasional untuk mengentas kemiskinan dan meningkatkan pemberdayaan ekonomi masyarakat peran BMT ( Baitul Maal wattanwil ) / koperasi Syariah sangat dibutuhkan masyarakat mengingat masyarakat sebagian besar menjadi pelaku usaha yang bergerak pada sektor usaha mitu jikro,di Indonesia lembaga perbankan mengalami kemajuan dan perkembangan yang meningkat, begitu juga bank syariah juga berkembang dengan baik dikarenakan penduduk Indonesia yang didominasi oleh umat Islam sehingga masyarakat mendambakan lembaga keuangan yang bukan hanya finacial melainkan semata dari segi moralitas.

Eksistensi kehadiran BMT jelas memiliki arti penting bagi pembangunan ekonomi syariah serta menjadi inti kekuatan ekonomi yang berbasis kerakyatan dan sekaligus menjadi penyangga utama sistem perekonomian nasional, karena lembag ini lahir dari rakyat untuk rakyat dengan sistem mengguakan prinsip bagi hasil usaha mikro. Oleh karena itu untuk pengembangan dan pemberdayaan ekonomi masyarakat khususnya usaha mikro yang belum maksimal untuk mengembangkan potensi ekonomi, salah satu kendala kegiatan usaha mikro disebabkan kekurangan pendanaan modal untuk mendapatkan pembiayaan dari lembaga keuangan yang berpola syariah.

Semakin berkembangnya perekonomian maka semakin meningkat pula kebutuhan masyarakat khususnya pelaku ekonomi mikro dalam pemenuhan pendanaan untuk membiayai kegiatan usaha mikro yang memiliki pendanaan terbatas untuk memenuhi operasional dan pengembangan usahanya, maka BMT dengansistem bagi hasil memegang peran penting dan stategis dengan persedian permodalan pengembangan sektor produktif.

Desa Sumberkolak merupakan desa idaman yang memiliki luas wilayah, 1.611.491 Ha, dengan jumlah penduduk 15.741 jiwa dari berbagai etnis 
mayoritas umat islam, dengan jumlah keluarga prasejahtera 1219 keluarga,pendapatan perkapita dari sektor usaha pertanian, perkebunan, peternakan, industri kecil dan kerajinan rumah tangga serta jasa, mempunyai potensi ekonomi yang produktif ,namun tingkat keluarga prasejahtera masih tinggi ,oleh karena itu untuk pengembangan dan pemberdayaan ekonomi masyarakat usaha mikro yang belum maksimal, salah satu kendala kegiatan usaha mikro disebabkan kekurangan modal untuk mendapatkan pembiayaan untuk memenuhi operasional dan pengembangan usahanya. Oleh karena itu didesa sumberkolak belum mempunyai lembaga keuangan yang berpola syariah untuk memenuhi pendanaan usaha mikro untuk pengembangan dan pemberdayaan sektor produktif

BMT (Baitul Maal wattamwil ) adalah lembaga keuangan mikro yang dioperasikan dengan prinsip bagi hasil, menumbuh kembangkan bisnis usaha mikro dan kecil,dalam rangka mengangkat derajat dan martabat serta membela kepentingan kaum fakir miskin yang beroperasi sesuai dengan prinsip prinsip syariah .

Menurut M Nur Rianto Arif ( 2011 : 377 ) Baitul Maal Wat Tanwil ( BMT ) atau Balai Usaha Mandiri terpadu adalah lembaga keuangan mikro yang di operasionalkan dengan prinsip bagi hasil, menumbuh kembangkan usaha mikro dalam rangka mengangkat derajat dan martabat serta membela kepentingan kaum fakir miskin ,ditumbuhkan atas prakarsa dan modal awal dari tokoh tokoh masyarakat setempat dengan berlandaskan pada sistem bagi hasil.

Pendirian dan pengembangan BMT dipengaruhi oleh potensi yang ada pada masyarakat. Potensi tersebut merupakan salah satu modal bagi BMT untuk dapat menarik masyarakat menjadi nasabahnya. BMT sebagai mitra bagi masyarakat tentunya memiliki hubungan yang erat dengan keadaan karena itu masyarakat tersebut, oleh karena itu perlu dukungan dari berbagai pihak untuk mengembangkan BMT seperti Para hartawan, pemeritah, ulama, tokoh masyaraakat serta masyarakat sendiri.Agar dapat bersatu untuk membantu BMT sehingga pemberdayaan eknomi umat, pengentasan kemiskinan, kesenjangan sosial dapat berkurang sehigga tercapainya keadilan ekonomi, kemakmuran dan 
kesejahteraan masyarakat dann terlebih tidak kalah pentingnya masyarakat miskin terbebas dari jeratan rentenir.Berdasarkan potensi yang dimiliki oleh masyarakat Desa Sumberkolak maka diperkirakan lembaga keuangan syariah dapat berkembang dengan baik di Desa Sumberkolak ini.

\section{METODE PENELITIAN}

\section{Lokasi dan Waktu Penelitian}

Penulis melakukan penelitian di desa Sumber Kolak ,salah satu desa yang ada di kecamatan Panarukan ,desa ini terdiri dari 8 dusun diantaranya : dusun tribungan, karajan barat, krajan timur, pareyaan utara,s, pareyaan selatan, langai, randu, Dam.

\section{Tehnik Penarikan Sampel}

Populasi dalam penelitian ini adalah semua masyarakat Desa Sumberkolak yang terdiri dari 8 dusun. Dari 8 dusun diantaranya dusun tribungan, krajan barat, krajan timur, pareyaan utara, pareyaan selatan, langai, randu, dam. Jumlah penduduk dari kedelapan dusun ini sebanyak 15.996 Jiwa.

Dalam Penelitian ini ,tehnik penarikan sampel untuk mewakili responden dengan mengunakan rumus Slovin ( Buchori ,2007 : 35 )

$$
\mathrm{n}=\frac{N}{1+N e 2}
$$

Keterangan :

$\mathrm{n}=$ Jumlah sampel

$\mathrm{N}=$ Populasi

$\mathrm{e}=$ taraf signifikan ,persen kelonggaran,ketidak telitian karena kesalahan pengambilan sampel.

Maka berdasarkan rumus slovin tersebut dengan kelonggaran $10 \%$ dapat diketahui junlah sampel yang akan diambil dari jumlah penduduk yang terdapat di desa sumberkolak, sebagai berikut:

$$
\begin{aligned}
& \mathrm{N}=\frac{15.996}{1+15.996(0,1) 2} \\
& =99,93
\end{aligned}
$$


Jadi jumlah sampel dalam penelitian ini sebanyak 99 responden . Pengambilan jumlah sampel pada masing- masing dusun ditentukan dengan memakai rumusan alokasi Proporsional kemudian dicari sampel berstrata dari masing-masing dusun dengan rumus :

$\mathrm{Ni}=(\mathrm{N}$ i : $\mathrm{N}) \times \mathrm{N}$
a. Trebungan $=1.390: 15.996 \times 99,93=9$
b. Krajan Barat $=1615: 15.996 \times 99,93=10$
c. Krajan Timur $=1585: 15.996$ X $99.93=10$
d. $\quad$ Pareyaan Utara $=1909: 15.996 \times 99,93=12$
e. $\quad$ Pareyaan Selatan $=2.277: 15,996 \times 99,93=14,2$
f. Langai $=3.139: 15.996 \times 99,93=20$
g. Randu = $2.902: 15.996 \times 99,93=18$
h. Dam $=1.179: 15.996 \times 99,93=7.3$

Pengambilan sampel yang akan diteliti ditentukan dengan sampling Purposive, Sampling Purposive dengan pertimbangan ( Sugiono, 2009:120 ) . Maka penentuan sampel pada penelitian ini dipilih yang memiliki kriteria :
a. Umur 17 sampai dengan 65 tahun
b. Sudah mempunyai pekerjaan
c. Bekerja di tempat penelitian
d. Bertempat tinggaln di wilayah penelitian

\section{Tehnik Analisis}

\section{Analisis Deskriptif}

Analisa data dilakukan dengan metode analisis deskriptif yang dilakukan dengan mendeskripsikan hasil surve yanhg diperoleh menggunakan kuisioner ( Fredy Rangkuti,2013 : 25 ).Penelitian ini analisis deskriptif kualitatif berupa tabel, dimana tabel tersebut menggunakan distribusi presentase dan nominal. 


\section{Analisis SWOT}

Analisis SWOT adaalah analisis kondisi internal mapun eksternal suatu organisasi yang selanjutnya akan digunakan sebagai dasar untuk merancang strategi dan program kerja, analisis internal meliputi penilaian terhadap faktor kekuatan ( Strength) dan kelemahan ( weakness ), sedangkan analisis eksternal mencakup faktor peluang ( Opportunity) dan ancaman ( Threaths) ( Freddy Rangkuti,2013 : 25 ). Sebelum membuat matriks strategi eksternal,kita perlu menegetahui terlebih dahulu faktor strategi eksternal. Berikut cara penentuan faktor strategi eksternal :

1. Susunlah dalam kolom1 (Peluang dan ancaman )

2. Beri bobot masing - masing faktor dalam kolom 3, mulai dari 1.00 sampai 0,00, faktor - faktor tersebut memberikan dampak terhadap faktor strategis.

3. Hitunglah rating dalam kolom 3 untuk masing - masing faktor memberikan skala mulai 4 sampai 1

4. Kalikan bobot pada kolom 3 dengan rating pada kolom 2 untuk memperoleh faktor pembobotan dalam kolom 4

5. Jumlahkan pada kolom 4 untuk memperoleh total skor pembobotan bagi organisasi yang bersangkutan. Nilai total ini menunjukkan bagaimana organisasi tertentu bereaksi terhadap faktor - faktor strategi eksternalnya.

Jika telah menyelesaikan analisa faktor faktor eksternalnya peluang dan ancaman, maka langkagh selanjutnya adalah menganalisis faktor strategi eksternal kekuatan dan kelemahan dengan cara yang sama. Setelah indikator SWOT ditentukan langkah pertama adalah bobot, rating, skor ( Fredy Rangkuti ,2013 : 36 -37 ).

Langkah kedua adalah menjumlahkan bobot kekuatan dan kelemahan, kemudian dihitung untuk masing - masing indikator yang terdapat pada kekuatan dan kelemahan, sehingga total bobot tersebut menjadi 1 atau 100\%. Dengan cara yang sama dihitung bobot dan bobot relatif untuk peluang dan ancaman.

Langkah ketiga adalah menentukan rating Rating adalah analisis kita terhadap kemungkinan yang akan terjadi .Rating adalah nilai dari faktor strategis perusahaan dengan skala 1 sampai 4 . Nilai skor diperoleh berdasarkan hasil nilai 
pembobotan dikali nilai rating. Selanjutnya digabung kedua kondisi internal dan eksternal ini selanjutnya kita masukkan dalam internal ekternal matrik, sehingga kita mengetahui posisi persaingan yang akan terjadi produk yang kita analisis. Berdasarkan posisi ini kita dapat menentukan strategi yang tepat untuk menentukan memenangkankan persaingan.

Sedangkan untuk menentukan titik sumbu $\mathrm{x}$ dan $\mathrm{y}$, kita melakukan pengurangan antara jumlah total faktor $\mathrm{S}$ dengan $\mathrm{W}$ dan faktor $\mathrm{O}$ dengan $\mathrm{T}$, perolehan angka $(\mathrm{a}=\mathrm{x}$ ) selanjutnya menjadi nilai atau titik pada sumbu $\mathrm{x}$, sementara perolehan angka $(b=y)$ selanjutnya menjasi nilai pada sumbu y.

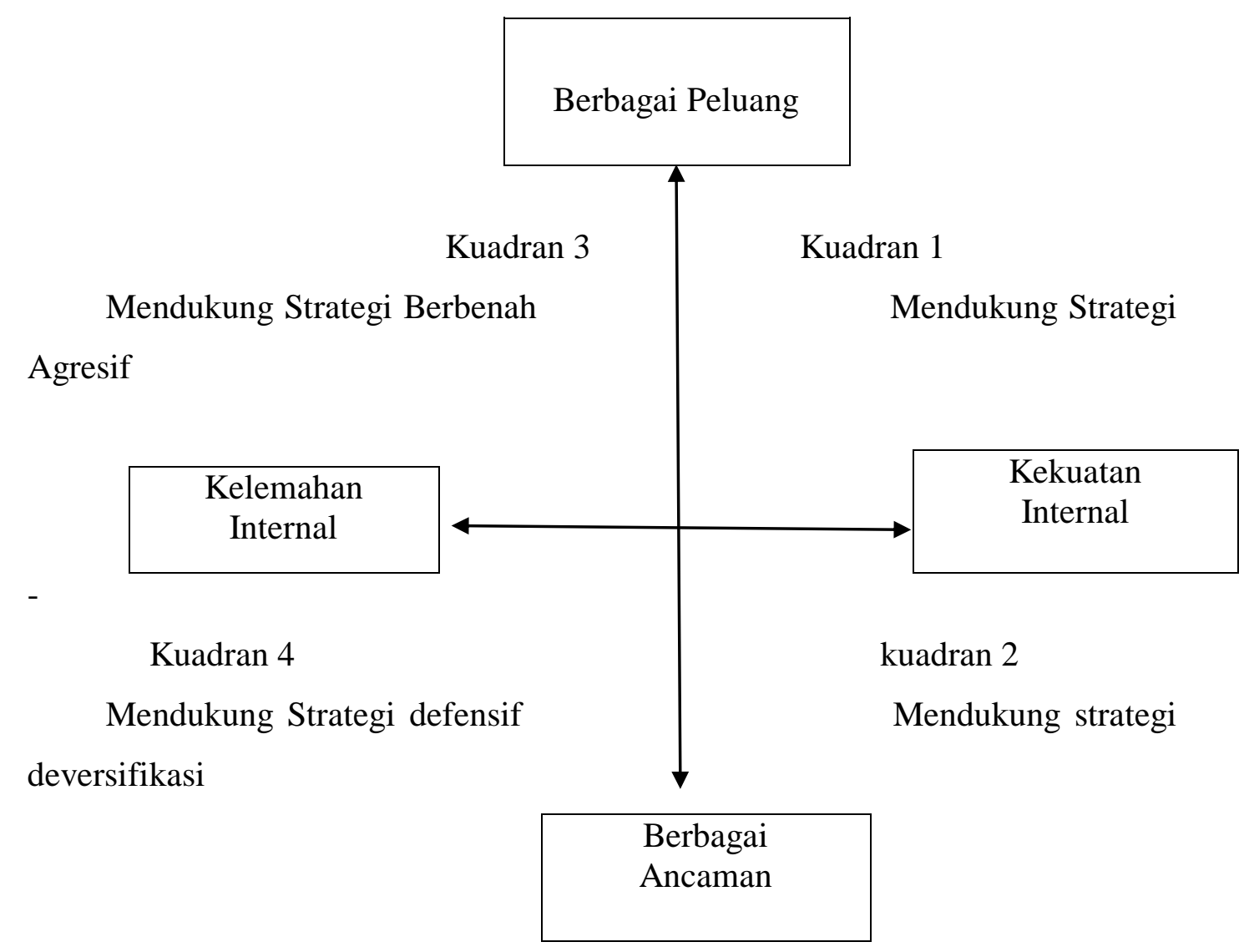

Gambar 1.Diagram analisa SWOT

(Fredy Rangkuti,2013 : 88 ) 
Dari Gambar 1 diatas dapat diketahui bagaimana Matriks kuadran SWOT yang dapat dijelaskan sebagai berikut :

1. Kuadran 1 : Merupakan situasi yang sangat menguntungkan organisasi tersebut memiliki kekuatan dan peluang sehingga dapat mengarahkan seluruh potensi internal organisasi untuk memanfaatkan peluang yang ada .strategiyang harus diterapkan dalam kondisi ini adalah mendukung kebijakan pertumbuhan yang agresif.

2. Kuadran II : meskipun menghadapi berbagai ancaman organisasi ini masih memiliki kekuatan dari segi internal strategi yang harus diterapkan adalah menggunakan kekuatan untuk memanfaatkan peluang jangka panjang dengan cara strategi diversifikasi.Diversifikasi yakni membuat strategi yang berbeda dengan memanfaatkan kekuatan internal,sehingga dimasa yang akan datang memungknkan terciptanya peluang.

3. Kuadran III : Organisasi mendapatkan pekuang ( Eksternal ) yang sangat besar,tetapi dilain pihak ,ia menghadapi beberapa kendala/kelemahan internal .Fokus organisasi ini adalah meminimalkan masalah masalah internal organisasi sehingga dapat merebut peluang dari luar tersebut dengan baik.

4. Kuadran IV : ini merupakan situasi yang sangat tidak menguntungkan ,organisasi tersebut menghadapi berbagai ancaman yakni mempertahankan diri untu membangun kekuatan internal dan meminimalkan kelemahan.

\section{HASIL DAN PEMBAHASAN}

Untuk dapat melihat dan menilai berpotensi atau tidaknya masyarakat terhadap potensi pendirian BMT guna meningkatkan pemberdatyaan ekonomi mikro di Desa Sumberkolak Panarukan Situbondodilakukan analisis internal dan eksternal dengan menggunakan analisis SWOT . Berdasarkan data yang telah diperoleh maka faktor internal dan eksternal tersebut dapat diidentifikasikan dan diuraikan sebagai berikut :

1. Analisis SWOT ( Strenght,Weakness,Opportunities, Threat )

a. Analisis Terhadap Faktor Internal daan Eksternal 
Analisis SWOT potensi masyarakat terhadap pendirian BMT di Desa Sumberkolak Kecamatan Panarukan Situbondo dilakukan analisis internal dan eksternal dengan menggunakan tehnik analisis SWOT berdasarkan data yang telah diperoleh maka faktor internal dan eksternal dapat diidentifikasikan dan diuraikan sebagai berikut :

1). Analisis Internal

(a). Analisis Kekuatan ( Srengths )

Berdasarkan tinjauan pustaka BMT maka dapat dirumuskan faktor kekuatan yang dimiliki oleh BMT. Adapun faktor kekuatan tersebut adalah :

(1). Bentuk Organisasi BMT sederhana

(2). Proses mendirikan BMT mudah

(3). Membuka Kesempatan Kerja

(4). Terjangkau kepada masyarakat

(5). Mandiri dan mudah mengalir di masyarakat

(6). Prosedur pembiayaan mudah

(b). Analisis Kelemahan (Weakness )

Adapun faktor kelemahan yang dimilki BMT adalah :

(1). Permodalan BMT masih relatif kecil

(2). Belum terkenal dikalangan masyarakat

(3). Sumber daya manusia masih terbatas

(4). Skala Usaha Mikro

(5). Sistem operasional dan prosedur belum Standart

2). Analisis Eksternal

(a). Analisis faktor Ancaman ( Threats )

Adapun faktor Ancaman yang dimiliki BMT adalah :

(1). Kemampuan sumber daya manusia yang terbatas

(2). Sebagian masyarakat kurang jujur 
(3). Banyak masyarakat yang belum mengenal BMT

(4). Masyarakat tidak gemar menabung

(5). Terdapat lembaga keuangan yang lain atau pesaing.

(b). Analisis faktor Peluang (Opportunities )

Adapun faktor peluang yang dimiliki BMT adalah :

(a). Masyarakat mendukung adanya BMT

(b). Adanya norma dan adat istiadat didalam keluarga

(c). Terdapat kebutuhan modal usaha mikro

(d). Masyarakat berada pada usia produktif

(e). Terdapat jenis pekerjaan masayarakat pada sektor pertanian ian informal.

(f). Masyarakatnya sintesis dan terbuka.

b. Menentukan Faktor Internal yang menjadi kekuatan dan kelemahan pada Tabel IFAS ( Internal Faktor Analysis Summary ) dan Faktor Ekstrenal yang menjadi Peluang dan Ancaman pada Tabel EFAS ( Eksternal Faktor Analysis Summary ).

Tabel 1. Faktor Internal

\begin{tabular}{|l|l|l|l|l|l|}
\hline No & Faktor Internal & Jumlah & Rating & Bobot & Bobot x Rating \\
\hline I & Kekuatan ( Strenghts ) & & & & \\
\hline 1. & Bentuk organisasi sederhana & 370 & 4 & 0,09 & 0,36 \\
\hline 2. & $\begin{array}{l}\text { Proses mendirikan BMT } \\
\text { mudah }\end{array}$ & 381 & 4 & 0,10 & 0,40 \\
\hline 3. & Membuka kesempatan kerja & 393 & 4 & 0,10 & 0,40 \\
\hline 4. & $\begin{array}{l}\text { Terjangkau kepada } \\
\text { masyarakat }\end{array}$ & 385 & 4 & 0,10 & 0,40 \\
\hline 5. & $\begin{array}{l}\text { Mandiri dan mudah mengalir } \\
\text { dimasyarakat }\end{array}$ & 377 & 3 & 0,10 & 0,30 \\
\hline 6. & Prosedur pembiayaan mudah & 395 & 4 & 0,10 & 0,40 \\
\hline & Total Kekuatan & & & & 2,26 \\
\hline
\end{tabular}


Tabel 2. Faktor Internal

\begin{tabular}{|l|l|l|l|l|l|}
\hline No & Faktor Internal & Jumlah & Rating & Bobot & Bobot x Rating \\
\hline II & Kelemahan (Weakness ) & & & & \\
\hline 1. & Permodalan masih kecil & 374 & 4 & 0,10 & 0,40 \\
\hline 2. & $\begin{array}{l}\text { Belum populer dikalangan } \\
\text { masyarakat }\end{array}$ & 289 & 2 & 0,07 & 0,14 \\
\hline 3. & $\begin{array}{l}\text { Sumber daya manusia masih } \\
\text { terbatas }\end{array}$ & 300 & 3 & 0,07 & 0,21 \\
\hline 4. & Skala usaha mikro operasional dan & 367 & 4 & 0,10 & 0,40 \\
\hline 5. & $\begin{array}{l}\text { Sistem } \\
\text { prosedur belum standart }\end{array}$ & 250 & 2 & 0,06 & 0,12 \\
\hline & $\begin{array}{l}\text { Total Kelemahan } \\
\text { Selisih total } \rightarrow \text { S-W }=2,26- \\
1,27=0,99=x\end{array}$ & & & 1,00 & 1,27 \\
\hline
\end{tabular}

Tabel 3. Faktor Eksternal

\begin{tabular}{|l|l|l|l|l|l|}
\hline No & Faktor Ekternal & Jumlah & Rating & Bobot & Bobot x Rating \\
\hline I & Opportunities ( Peluang ) & & & & \\
\hline 1. & $\begin{array}{l}\text { Masyarakat mendukung } \\
\text { adanya BMT }\end{array}$ & 410 & 4 & 0,10 & 0,40 \\
\hline 2. & $\begin{array}{l}\text { Adanya norma dan Adat } \\
\text { istiadat di dalam keluarga }\end{array}$ & 409 & 4 & 0,10 & 0,40 \\
\hline 3. & $\begin{array}{l}\text { Terdapat kebutuhan modal } \\
\text { usaha }\end{array}$ & 411 & 4 & 0,10 & 0,40 \\
\hline 4. & $\begin{array}{l}\text { Masyarakat berada pada usia } \\
\text { produktif } 384\end{array}$ & 3 & 0,09 & 0,27 \\
\hline 5. & $\begin{array}{l}\text { Terdapat jenis pekerjaan } \\
\text { masyarakat pada sektor } \\
\text { Pertanian dan Informal }\end{array}$ & 410 & 4 & 0,10 & 0,40 \\
\hline 6. & $\begin{array}{l}\text { Masyarakatnya Sintesis dan } \\
\text { Terbuka }\end{array}$ & 387 & & 1,00 & 1,27 \\
\hline & Total Peluang & & & & 2,14 \\
\hline
\end{tabular}

Table 4. Faktor Eksternal

\begin{tabular}{|l|l|l|l|l|l|}
\hline No & Faktor Eksternal Jumlah & Rating & Bobot & Bobot x Rating \\
\hline II & Ancaman ( Treats ) & & & & \\
\hline 1. & $\begin{array}{l}\text { Kemampuan sumber daya } \\
\text { manusia yang terbatas }\end{array}$ & 395 & 3 & 0,08 & 0,24 \\
\hline 2. & $\begin{array}{l}\text { Sebagian masyarakat kurang } \\
\text { jujur }\end{array}$ & 455 & 0,09 & 0,36 \\
\hline 3. & $\begin{array}{l}\text { Banyak masyarakat yang } \\
\text { belum mengenal BMT gemar }\end{array}$ & 388 & 4 & 0,09 & 0,36 \\
\hline 4. & Masyarakat tidak gemak & 4 & 0,08 & 0,32 \\
\hline
\end{tabular}




\begin{tabular}{|l|l|l|l|l|l|}
\hline & menabung & & & & \\
\hline 5. & $\begin{array}{l}\text { Terdapat lembaga keuangan } \\
\text { yang lain atau pesaing }\end{array}$ & 380 & 4 & 0,08 & 0,32 \\
\hline Total Ancaman & & & 1,00 & 1,6 \\
\hline $\begin{array}{l}\text { Selisih total } \rightarrow \mathrm{O}-\mathrm{T}=2,14 \\
-1,6=0,54=\mathrm{y}\end{array}$ & & & \\
\hline
\end{tabular}

Untuk melihat posisi potensi pendirian BMT guna meningkatkan pemberdayaan ekonomi mikro di Desa Sumberkolak Panarukan Situbondo dari analisa SWOT terdapat pada Matriks Kuadran SWOT pada gambar 3 sebagai berikut :

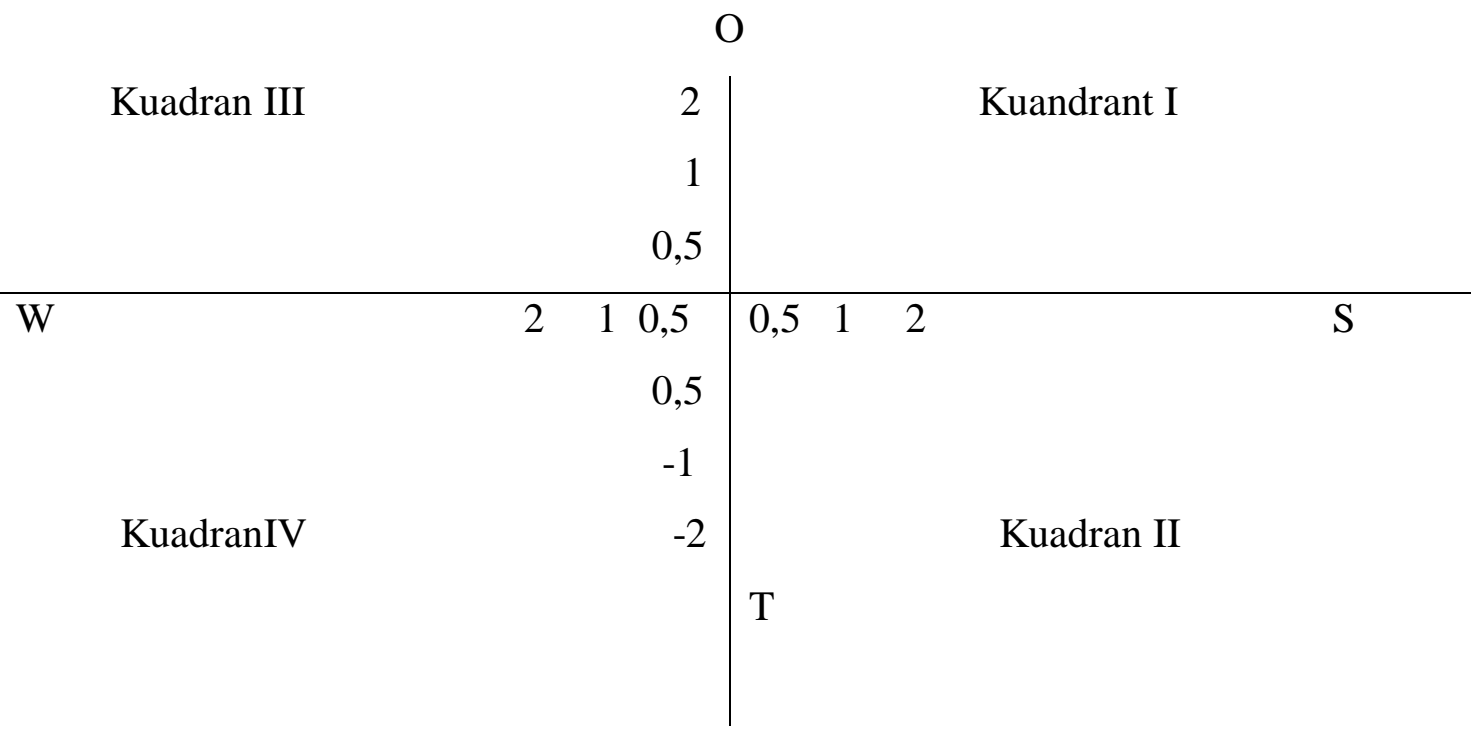

Gambar 3. Matriks Kuadran SWOT

SWOT menurut Kotler ( 2008 : 88 ) mengemukan bahwa analisa SWOT adalah Evaluasi terhadap keseluruhan kekuatan, kelemahan, peluang dan ancaman, dengan menentukan faktor Internal yang menjadi kekuatan dann kelemahan dengan menggunakan tabel IFAS ( Internal Faktor Analysis Summary ) dan faktor Eksternal yang menjadi peluang dan ancaman dengan menggunakan tabel EFAS ( Eksternal Faktor Analysis Summary) di desa Sumberkolak Panarukan diperoleh selisih total Strength 2,26 dan weakness 1,27 adanya selisih 
sebesar 0,99. Sedangkan faktor eksternal yang menjadi Peluang dan Ancaman diperoleh selisih total Oppotunities 2,14 dan treats 1,6 adanya selisih sebesar 0,54.

Analisa SWOT digunakan sebagai penentu kebijakan strategi organisasi dalam memaksimalkan faktor kekuatan dan memanfaatkan peluang yang ada sekaligus berperan memperkecil kelemahan yang ada dalam organisasi serta menekan berbagai ancaman yang akan timbul. Untuk mengetahui posisi potensi pendirian BMT dengan masyarakat guna meningkatkan pemberdayaan ekonomi di Desa Sumberkolak Panarukan Situbondo pada Matriks Kuadrant SWOT ( Fredy Rangkuti ,2013 : 13 ).

Pada gambar Matriks SWOT dapat diketahui bahwa posisi pendirian BMT dengan potensi masyarakat yang ada berada pada Kuadrant 1 yaitu $0,99=\mathrm{x}$ dan $0,54=\mathrm{y}$. sehingga dijelaskan bahwa pada posisi ini merupakan situasi yang sangat mengntungkan organisasi memliki peluang dan kekuatan sehingga dapat memanfaatkan peluang yang ada, strategi yang harus diterapkan dalam posisi ini adalah mendukung kebijakan yang agresif atau strategi yang progresif ,masyarakat Desa Sumberkolak memiliki potensi untuk melakukan pendirian BMT di daerah penelitian.

d.Luaran yang dicapai

Luaran yang dicapai dari Analisis SWOT ini adalah :

1. Adanya rekomendasi sosialisasi pada masyarakat Desa Sumberkolak Panarukan Situbondo potensi pendirian BMT guna meningkatkan pemberdayaan ekonomi mikro.

2. Adanya Artikel ilmiah sebagai bahan acuan potensi pendirian BMT di Desa Sumberkolak panarukan Situbondo. 


\section{KESIMPULAN DAN SARAN}

\section{Kesimpulan}

Dari hasil penelitian potensi masyarakat dalam pendirian BMT di Desa Sumberkolak dapat disimpulkan bahwa :

1. Dari hasil analisis deskriptif dapat diketahui beberapa potensi masyarakat yang dapat menjadi peluang dan ancaman terhadap potensi pendirian BMT.

2. Hasil dari analisis SWOT Penilian terhadap Faktor Internal kekuatan dan kelemahan yang dimiliki BMT menunjukkan hasil yang positif tapi lemah yaitu terdapat selisih antara kekuatan dan kelemahan yang dimiliki BMT sebesar 0,99. Sedangkan dari faktor eksternal diketahui bahwa terdapat selisih total penilaian antara peluang dan ancaman yaitu sebesar 0,54. Sehingga dapat diketahui dari penelitian masih membutuhkan upaya sosialisasi yang lebih intensif terhadap pengenalan BMT sehingga masyarakat Desa Sumberkolak lebih mengetahui dan memahami mengenai BMT .

3.Hasil dari Matriks analisis SWOT menunjukkan bahwa matrik berada pada kuadran 1 ini berarti menujukkan strategi agresif dan progresif .

\section{Saran}

Berdasarkan pembahasan dan simpulan di atas maka beberapa nsaran yang dapat penulis berikan adalah :

1. Masyarakat Desa Sumberkolak Panarukan masih banyak yang belum mengenal BMT, hanya $30 \%$ dari total responden yang mengetahui atau mendengar BMT. Ini menunjukkan bahwa, di daerah penelitian ini masih dibutuhkan upaya sosialisasi dan penyuluhan yang lebih intensif terhadap pengenalan BMT sehingga masyharakat lebih mengetahui dan memahami mengenai BMT guna pemberdayaan ekonomi mikro 
2. Hasil analisis Matrik SWOT menunjukksn bahwa matrik berada pada kuadran 1 ini berarti, bagi pihak pihak masyarakat, para hartawan, Ulama , masyarakat yang peduli yang ingin mendirikan BMT di daerah penelitian ini sangat positif tapi lemah.

3. Bagi pemerintah khususnya Desa Sumberkolak, perlu adanya perhatian lebih serius terhadap pengembangan BMT. Karena BMT bisa menjadi salah satu alternatif membrantas kemiskinan melalui pemberdayaan ekonomi mikro.

\section{DAFTAR PUSTAKA}

Aziz,A dan Ulfah, M. (2010). Ekonomi Islam kontemporer. Bandung: Alfabeta

Arif Al Nur, R. (2011). Dasar dasarEkonomi Islam. Solo: Era Adicipta Intermedia

Buchori. (2011). Belajar Muda untuk peneliti pemula,Penerbit Uham Press

Kotler, P.dan Keller Levin ,L. (2000). Manajemen Pemasaran. Jakarta: Indeks

Naf an, (2014).Pembiayaan Musyarakah dan Mudharabah. Yogyakarta: Graha Ilmu

Pinbuk. (201). Pusat Inkubasi bisnis Usaha Kecil. Jakarta: Press Pinbuk

Rangkuti, F. (2013). Analisis SWOT, Tehnik membedah kasus Bisnis. Jakarta: PT Gramedia jakarta

Sugiono. (2014). Metode Penelitian Kualitatif. Bandung: Alfabeta 